\title{
A Forma do Paradoxo: Friedrich SCHLEgel E A Ironia Romântica
}

\author{
Constantino Luz de Medeiros ${ }^{l}$
}

RESUMO: Definida como beleza lógica e forma do paradoxo, a ironia romântica de Friedrich Schlegel (1772-1829) assimila a antiga ironia socrática e a reinterpreta, inserindo-a como elemento central de sua teorização crítico-literária. O presente artigo analisa a ironia romântica, buscando situar sua alteração e abrangência no final do século XVIII, quando o conceito passa a significar metacrítica, reflexão filosófica, ruptura ficcional, distância estética e forma de exposição da arte literária.

PALAVRAS-CHAVE: Friedrich Schlegel. Ironia Romântica. Ironia Socrática. Estética. Primeiro Romantismo Alemão.

Ironia é a forma do paradoxo. Paradoxo é tudo aquilo que é ao mesmo tempo bom e grande. (SCHLEGEL, 1991, p. 28).

A necessidade de encontrar a solução para o problema da objetividade na obra de arte literária moderna é um dos fundamentos do conceito de ironia romântica de Friedrich Schlegel, o qual deve ser compreendido no contexto de sua teorizaçáo sobre a poesia moderna, realizada principalmente no texto Sobre o estudo da poesia grega, Über das Studium der griechischen Poesie (SCHLEGEL, 1979, p. 267). Escrito entre os anos de 1795 e 1796, o Studium-Aufsatz, como é conhecido, tem como uma de suas preocupaçóes centrais a busca por um princípio interno organizador para a poesia moderna. A partir da constatação de que a poesia grega havia descoberto o segredo de permanecer objetiva, embora tratasse de matéria individual, Schlegel (1979, p. 321) chega à conclusão de que a saída para esse paradoxo requereria uma força artística a qual pudesse regular, ao mesmo tempo, sujeito e objeto, natureza e liberdade, unificando e separando o real e o ideal na obra de arte literária. A ironia romântica, enquanto atitude que se fundamenta na

\footnotetext{
${ }^{1}$ Doutorando e bolsista FAPESP pelo Programa de Pós-Graduação em Teoria Literária e Literatura Comparada da Universidade de São Paulo - USP. E-mail: constantinoluz@up.br
} 
clareza de consciência, deveria ser capaz de propiciar ao autor a distância estética necessária em relação à sua própria obra. Desse modo, ela representa a força motriz aglutinante, o princípio interno organizador entre os âmbitos da crítica, da reflexão filosófica, da criação e da exteriorização literária. O texto que se segue busca compreender o desenvolvimento do conceito de ironia romântica de Friedrich Schlegel. Para isso, será investigada a distinção realizada pelo crítico entre ironia socrática e ironia romântica. Com o mesmo propósito, será analisada a assimilação de alguns termos advindos da tradição literária e da filosofia, bem como as severas restriçóes impostas ao conceito de ironia romântica por G. W. F. Hegel (1770-1831). As questóes inerentes à comunicação total e à ininteligibilidade, inseridas na teoria de Schlegel, auxiliarão na compreensão da ironia romântica enquanto locus de reflexão crítica, forma de exposição da arte e busca pela perfectibilidade infinita, no espaço da criação literária.

\section{IRONIA SOCRÁTICA E IRONIA ROMÂNTICA}

Em seu sentido original, a palavra grega eïp $\omega v$ [eiron] significava “[...] aquele que fingia não saber ou não conhecer do assunto tratado, que falava ou agia com dissimulação com o intuito de mascarar, esquivar e ocultar algo" (CUDDON, 1999, p. 428). Advinda do indo-europeu uerh, onde denotava "falar seriamente", o termo seria incorporado ao grego, alterando seu significado para o campo semântico da dissimulação (BEEKS, 2010, p. 393). Segundo o estudioso da tradição literária J. A. Cuddon (1999, p. 428), a figura do irônico representava, na comédia grega, a dissimulação que ocorria através da ação do homem que não se mostrava inteiramente à luz, diminuindo-se intencionalmente em face do oponente, o alazon, o sujeito fanfarrão que supunha saber mais do que em realidade sabia. Nas obras de Aristófanes (Séc. $\mathrm{V}$ a. C.), a palavra eiron estava relacionada ao ataque verbal, o subterfúgio, e à intenção de ridicularizar o oponente através do deslocamento intencional do discurso (KNOX, 1973, p. 21). Essa mesma acepção é apontada por Ernst Behler (1997, p. 23), o qual afirma que a ironia em Aristófanes diz respeito ao âmbito da injúria, e que o eiron indicava alguém de caráter manhoso e pérfido, caracterizado em paralelo ao alazon, na Antiguidade. Como é possível perceber, em sua origem, a ironia contrasta decisivamente daquela ideia de urbanidade e de diálogo reflexivo que viria a ter, mais tarde, com Sócrates (Séc. IV a. C.). Mas, é com o filósofo grego que o conceito ganha a dimensão e a importância que conservaria na posteridade, de modo que "[...] o desenvolvimento do 
conceito de ironia não pode ser separado da personalidade e da influência de Sócrates" (KNOX, 1973, p. 21). O jogo dialético, estabelecido pelo filósofo grego para determinar a validade de seus argumentos, pressupunha a escolha da estratégia de ocultar intencionalmente o que sabia sobre o assunto para levar o oponente ao conhecimento da verdade. Todavia, diferentemente da acepção originária do eiron, que buscava desqualificar o adversário de um modo muitas vezes grosseiro, Sócrates é exemplo de urbanidade. É por essa razão que a ironia socrática representou uma nova possibilidade de exteriorização e reflexão filosófica, para Friedrich Schlegel. A aparição da ironia em qualquer lugar, não se restringindo apenas ao discurso na assembleia, ao foro privilegiado das discussôes do tribunal, indicaria outra característica singular da atitude irônica no filósofo grego: a atopia:

Como nenhum outro homem, Sócrates é atópos, “atópico", isto é: está fora de lugar, fora do caminho ou do comum, é estranho, extraordinário, singular, paradoxal [...] Sócrates jamais perde seu aspecto incompreensível, e seria por isso ingênuo tentar separar nele o fundo da superfície. $\mathrm{O}$ mesmo ocorre com a ironia romântica: não tem cabimento querer separar a intenção sincera de sua expressão involuntária, distinguindo rigorosamente a seriedade de todo aspecto lúdico. Tentar estabelecer uma demarcação rigorosa entre a intenção sincera e a expressão involuntária, a seriedade e o jogo, é pôr a perder as duas coisas. (SUZUKI, 1998, p. 178).

Assimilando essa noção socrática da atopía, a ironia romântica se revela como uma atitude de espírito presente em toda parte, perpassando as mais diversas formas de exteriorização literária. Porém, enquanto, em Sócrates, o debate de ideias ocorria com um interlocutor "real", na ironia romântica, o artista reflete por meio do diálogo consigo mesmo, no interior da obra de arte literária. Como sentido artístico da vida, a ironia exige um elevado discernimento do jogo entre seriedade e brincadeira, assim como a lucidez e a clareza de consciência para reconhecer que há sempre algo de indizível, de incomunicável na comunicação humana. Esse estado de espírito liberal, na terminologia schlegeliana, que sabe da necessidade irrevogável de comunicação total, mas também da impossibilidade de sua realização, busca através da ironia romântica se distanciar de um assunto, de modo a poder voltar a ele, alçandose acima de sua própria criação para se expressar com a lucidez [Besonnenheit] necessária. Ao propiciar o distanciamento estético do artista em relação à sua obra, a ironia torna-se um elemento fundamental para a criaçáo literária, pois, para poder escrever de forma razoável sobre determinado assunto, “[...] 
é preciso já não se interessar por ele; o pensamento que se deve exprimir com lucidez já tem de estar totalmente afastado, já não ocupar totalmente alguém" (SCHLEGEL, 1991, p. 25). Instrumento e agente da reflexão metacrítica que ocorre com o distanciamento estético, e, ao mesmo tempo, necessária para que o poeta-filósofo possa realizar o movimento simultâneo de entrar e sair de si, a ironia romântica representa a possibilidade de autolimitação na obra literária. Como pressupunha a elevação dos interlocutores acima do tema escolhido, de maneira a possibilitar a observaçáo de uma questáo a partir de diversos ângulos, ela leva igualmente em consideração o fato de que "[...] a maioria dos artistas seria capaz de se elevar acima de suas próprias obras” (SCHLEGEL, 1991, p. 33). Atuando como elemento interno organizador que possibilita a ação recíproca entre a reflexão metapoética do autor e a exteriorização literária objetiva, o jogo irônico torna-se significativo para o processo de criação, porque favorece um locus privilegiado, a partir do qual o artista pode contemplar a obra e o ato de criação. O referido caráter acósmico de Sócrates, isto é, o fato de não pertencer a lugar algum e, ao mesmo tempo, a todos os lugares, é assimilado pelo crítico, o qual considerava que a ironia poderia estar em toda parte ou em lugar nenhum. Tal constatação levaria Schlegel a pensar que "[...] ela já se instalou na própria língua” (SUZUKI, 2007, p. 180, grifo do autor). A urbanidade e o dialogismo da ironia socrática seriam incorporados pela ironia romântica. Mas, enquanto, em Sócrates, a estratégia irônica visava a demonstrar ao interlocutor o equivoco de sua pressuposta certeza do conhecimento, na ironia romântica, esse diálogo se realiza entre o artista e sua consciência.

Como demonstra Ernst Behler (1972, p. 18), Aristóteles (384-322 a. C.) acreditava que a ironia pertencia ao âmbito da retórica e da ética, pois, como era uma estratégia de persuasão, seu uso não poderia ser indiscriminado, sendo necessário saber até que ponto era conveniente, bom ou decoroso persuadir. Por essa razão, o filósofo grego trata da ironia enquanto forma negativa de desvio da verdade, na Ética a Nicômaco, e como uma nobre forma de gracejo ou brincadeira, na Retórica. Em seu sentido de persuasão e dissimulação, a ironia foi incorporada às estratégias da retórica clássica. A questão do decoro, ou seja, a importância de reconhecer se era adequado utilizar a ironia como forma de persuasão, foi ainda levantada por Cícero (106-43 a. C.), autor responsável pela introdução do termo em língua latina. Cícero descrevia a ironia como uma forma de dissimulatio urbana, ou seja, enquanto mescla de "[...] seriedade e jogo, que percorre todo o discurso sem que seja possível isolar os elementos de que é composta, pois se passa o tempo todo dizendo o contrário do que 
se pensa" (SUZUKI, 1998, p. 173). Nos livros VIII e IX de sua Institutio Oratoria, Quintiliano (35-95 d. C.) também alude à ironia como forma de se dizer o oposto do pensado, sua compreensão do fenômeno remete também à dissimulação de Sócrates (QUINTILIANO IX, 2, 46 apud BEHLER, 1972, p. 37). Esse conceito clássico de ironia permanece praticamente inalterado até o século XVIII, quando passa a ter o significado de uma "[...] atitude e consciência do jogo que se dá na obra sobre a própria obra” (BEHLER, 1972, p. 45).

No primeiro romantismo alemão, a urbanidade se revela na profusão de obras com eminente viés dialógico. São escritos que trazem o título de carta, ensaio, relato, descrição, diálogo, fragmento, confissão e conversa, exteriorizando aquela atmosfera de expansão da consciência e busca do conhecimento que a ironia socrática propiciava, e que fora incorporada pelos românticos. A ironia poderia ser encontrada ainda no filosofar e poetizar em conjunto, harmonicamente, que seria denominado por Schlegel e Friedrich von Hardenberg, o Novalis, (1772-1801), como o simpoetizar e sinfilosofar. Advindos da Antiguidade clássica, esses temas foram assimilados à ironia romântica schlegeliana. Enquanto brincadeira séria e reflexão dialógica, a ironia constitui uma saída para o paradoxo da impossibilidade de comunicaçáo total, sendo um dos temas centrais de alguns fragmentos de Schlegel:

A ironia socrática é a única dissimulação inteiramente involuntária e, no entanto, inteiramente lúcida. Fingi-la é tão impossível quanto revelá-la. Para aquele que não a possui, permanece um enigma, mesmo depois da mais franca confissão. Não se deve enganar ninguém, a não ser aqueles que a tomam por engodo e que, ou se alegram com a grande pândega de se divertir com todo mundo, ou ficam fulos, quando pressentem que também estão sendo visados. Nela tudo deve ser gracejo e tudo deve ser sério: tudo sinceramente aberto e tudo profundamente dissimulado. Nasce da unificação do sentido artístico da vida e do espírito científico, do encontro de perfeita e acabada filosofia-de-natureza e de perfeita e acabada filosofia-de-arte. Contem e excita um sentimento do conflito insolúvel entre incondicionado e condicionado, da impossibilidade e necessidade de uma comunicação total. É a mais livre de todas as licenças, pois por meio dela se vai além de si mesmo; e, no entanto, é também a mais sujeita à lei, pois é incondicionadamente necessária. É muito bom sinal se os harmoniosamente triviais não sabem de modo algum como lidar com essa constante autoparódia, na qual sempre acreditam e da qual novamente sempre desconfiam, até sentir vertigens, tomando justamente o gracejo como seriedade, e a seriedade como gracejo. (SCHLEGEL, 1991, p. 36). 
A partir de Friedrich Schlegel, a ironia passa a significar a reflexão e a metarreflexão artísticas, descrevendo a atitude daquele que cria perante sua própria obra e existência, sendo igualmente, portanto, uma reflexão filosófica. Como afirma Ingrid Strohschneider-Kohrs (2002, p. 14), esse deslocamento do sentido e da aplicação da ironia socrática à ironia romântica também representa a busca por algo que pudesse realizar ou resolver uma das questóes centrais de seus escritos sobre a Antiguidade clássica: a questão da objetividade da obra de arte literária. Com Schlegel, a figura de Sócrates é assimilada e inserida na ironia romântica, onde passa a significar a reflexão filosófica e a metacrítica, demonstrando e expondo os limites do artista e da arte, no jogo ao mesmo tempo sério e lúdico da literatura.

\section{IRONIA É PARÁBASE PERMANENTE}

Se a assimilação da ironia socrática à ironia romântica foi uma das formas encontradas pelo crítico para recuperar a antiga ironia em seu caráter urbano, mesmo que transferindo "[...] a urbanidade antiga para o plano suprassensível do reino dos espíritos" (SUZUKI, 1998, p. 175), a incorporação de diversos termos da tradição literária também fez parte desse esforço. Assim, no intuito de definir esse fenômeno, é necessário observar a terminologia utilizada por Schlegel para estabelecer o conceito de ironia romântica. Advindos da tradição literária, termos como "parábase", "bufão", "forma do paradoxo" ou ainda "bufoneria transcendental”, auxiliaram Schlegel em sua transposição da ironia socrática para a ironia romântica. Como demonstra J. E. Vendramini (2002, p. 57), o bufẫo era um dos personagens da commedia dell'arte, gênero de teatro popular que vigorou entre os séculos XVI e XVII, na Europa. Esse tipo de encenaçáo teatral foi desenvolvido principalmente na Itália medieval, onde grupos ou associaçóes de artesóes, os "arti", de onde o gênero deriva seu nome, apresentavam-se nas praças e mercados populares (CUDDON, 1998, p. 160). As apariçóes bufonescas, ainda de acordo com J. E. Vendramini (2002, p. 62), tinham o intuito de entreter o público nas feiras e praças, e preparar a entrada em cena de outros atores, de forma que sua atuação era calcada no improviso e no arranjo espontâneo. Essa personagem representava ainda o papel do dramaturgo, encenando uma autocrítica e apontando para eventuais enganos ou excrescências na encenaçáo.

Ao atuar como o próprio autor, o bufăo personificava o deslocamento irônico da crítica para o momento da encenação, e não enquanto instância 
que atua normalmente a posteriori. Essa metacrítica realizada pelo bufấo foi deduzida por Schlegel, que inseriu esse elemento da tradição literária em sua teoria da ironia romântica. Nesse sentido, através da figura insólita do bufẵo, o crítico também enfatiza o desenvolvimento do discurso irônico como forma de instância crítica. No fragmento 42 da Lyceum, o crítico acrescenta uma variação ao termo "bufấo", introduzindo o conceito inusitado de "bufonaria transcendental": "Há poemas antigos e modernos que respiram, do início ao fim, no todo e nas partes, o divino sopro da ironia. Neles vive uma bufonaria realmente transcendental" (SCHLEGEL, 1991, p. 26). O adjetivo "transcendental", que remete aos escritos de Fichte, significa que nesse tipo de ironia a reflexão sobre o processo criador ocupa o lugar central, assim como o "eu" na filosofia fichteana. A bufonaria transcendental indica a ação do autor que reflete sobre as condições de existência da obra, como a poesia que reflete sobre si mesma, enquanto exteriorização artística "[...] cujo um e tudo é a proporção entre ideal e real e que, portanto, por analogia com a linguagem técnica filosófica, teria de se chamar poesia transcendental" (SCHLEGEL, 1991, p. 88). Rindo constantemente de sua própria tolice, o bufấo é a atitude do crítico e do autor, os quais se encontram imbuídos do espírito da ironia e devem, portanto, ter a clareza de consciência [Besonnenheit] de saber que o processo artístico é infinito em sua reflexão sobre si mesmo.

$\mathrm{Na}$ ironia romântica, o bufẵo representa o poeta o qual reflete sobre o seu fazer artístico enquanto observa o processo criativo. Essa capacidade de se elevar acima de sua própria criação, transformando em arte a consciência da limitação artística e a referida constatação da impossibilidade da comunicação total, é representada por Schlegel no conceito de bufonaria transcendental. Mas, como foi ressaltado, a bufoneria atua em um duplo movimento. Internamente, ela significa a problematização do artista sobre sua obra, e sobre o processo de criação literária, ou seja, é reflexão filosófica e metacrítica. Já no exterior, ela brinca com a seriedade das reflexôes filosóficas do bufão transcendental, apontando para o paradoxo da arte e da vida em uma "[...] maneira mímica de um bom bufão italiano comum” (SCHLEGEL, 1991, p. 26). Expresso de outro modo, enquanto o bufẫo transcendental, em uma atitude filosófica, se eleva acima de si mesmo, "[...] acima de sua própria arte, virtude ou genialidade, o bufẫo italiano comum, ri de seus pensamentos excessivamente sérios, e não deixa, com isso, que o filósofo se afaste da vida" (SUZUKI, 1998, p. 180). 
Outro termo advindo da tradição literária e incorporado à concepção de ironia romântica de Schlegel é a "parábase". Originária da comédia grega, encontrando-se presente nas comédias de Aristófanes (séc. IV a. C.), comediógrafo muito admirado por Friedrich Schlegel, a parábase representa uma das seçóes da estrutura da comédia onde o coro se dirige diretamente à audiência (CUDDON, 1998, p. 634). A atuação do coro, na parábase, geralmente se dava através de falas que continham o ponto de vista do autor, de modo que Schlegel a utilizaria para definir a presença do artista no movimento autorreflexivo e metacrítico da ironia romântica. A ruptura na encenaçáo, realizada pelo coro na parábase, seria compreendida por Schlegel como uma atitude análoga ao emergir do autor a partir de sua obra. Segundo Friedrich Schlegel (1963, p. 85), a ironia romântica deveria ser compreendida como uma "parábase permanente", o que no âmbito da literatura significaria uma atitude constante e contínua de reflexão e autocrítica que deve ocorrer na obra de arte.

Com o significado mais profundo de um emergir em meio à encenação, tanto o bufấo italiano quanto o coro na parábase grega são figuras as quais remetem para uma espécie de instância metacrítica e autoral; uma atitude artística e reflexiva, inserida por Schlegel no centro de sua teorização sobre a ironia. $\mathrm{O}$ conceito de ironia romântica também pode ser compreendido como uma espécie de pêndulo que oscila entre dois âmbitos, o comum e o transcendental. Em seu eterno ir e vir, funcionando como um perpetuum mobile de criação, reflexão e crítica, o fenômeno da ironia deixaria marcas do infinito no finito. Pela autolimitação do artista, em sua elevação sobre a própria arte, a ironia romântica permitiria a contemplação para fora do âmbito finito e limitado da condição humana. Essa atitude irônica, que "[...] contém e excita um sentimento do conflito insolúvel entre o condicionado, da impossibilidade e necessidade de uma comunicação total" (SCHLEGEL, 1991, p. 36), é o instrumento indispensável na busca pela ação recíproca entre os modos de criação do artista, sendo também o agente propulsor de sua autonomia artística.

Todavia, para que o artista seja capaz de refletir e criar simultaneamente, e para que possa ainda representar a ironia como forma de exposição da arte em sua obra, uma série de movimentos é necessária. Schlegel (1991, p. 25) denomina essa série necessária de movimentos do espírito criador de "autocriação" [Selbstschöpfung], "autoaniquilamento" [Selbstvernichtung] e "autolimitação" [Selbstbeschränkung]. Essas três instâncias da ironia, ou processos de criação 
artística, podem ser compreendidas de um modo mais claro, substituindo-se a complexa terminologia fichteana utilizada por Schlegel. A autocriação representa o momento espontâneo de criação artística. $\mathrm{O}$ autoaniquilamento é a reflexão e autocrítica que o artista é capaz de fazer sobre sua obra. Esse movimento também significa o ato de "aniquilar" a própria obra, recriando-a em um nível mais elevado, assim como a observaçáo crítica do processo. Por outro lado, a autolimitação indica o distanciamento que o criador necessita, ao elevar-se sobre sua arte, para poder desenvolver de modo artístico e irônico aquilo que foi capaz de compreender a partir da autolimitação.

Para Ernst Behler (1997, p. 110), a terminologia e a sistemática adotadas por Schlegel para definir os modos de atuação do espírito criador no âmbito da arte são deduçóes que o crítico fez, com base em seus estudos da filosofia de Fichte. Grande parte do significado que o autor da Doutrinada-ciência (1794) teve para Friedrich Schlegel advém do fato de ele ter colocado a liberdade humana como o objetivo supremo de suas reflexões filosóficas. Para Fichte, a destinação da existência humana estava intimamente relacionada ao âmbito da liberdade e do aperfeiçoamento infinito, de forma que a criação artística, por meio do procedimento irônico, poderia elevar-se a uma consciência superior, um "pensar superior", na terminologia de Fichte (FICHTE, 1971, p. 108). De acordo com esse processo, a autolimitaçáo irônica é responsável pelo distanciamento estético necessário para a reflexão e a construção de sentido na criação artística. É o que denota Friedrich Schlegel, quando afirma que "[s]entido é autolimitação, ou seja, um resultado de autocriação e autoaniquilamento" (SCHLEGEL, 1981, p. 102). Desse modo, a autolimitação surge da relação recíproca entre autocriação e o autoaniquilamento. Elementos essenciais no processo criativo, a autocriação e o autoaniquilamento determinam a importância de uma obra de arte literária, pois “[...] o que não se aniquila não tem valor" (SCHLEGEL, 1981, p. 103), e, sem o distanciamento necessário que a autolimitação fornece, nenhum artista é capaz de criar. O termo "autoaniquilar" também é usado em diversos fragmentos de Schlegel como sinônimo de ironizar, o que poderia parecer uma tautologia, já que o autoaniquilamento é um dos processos da denominada ironia romântica (SCHLEGEL, 1981, p. 103). O processo irônico que envolve as atitudes de autocriação, autoaniquilamento e autolimitação está presente, de modo central, no fragmento 37 da Lyceum, onde Schlegel aponta para o papel preponderante da distância estética na criação literária:

Para poder escrever bem sobre um objeto, é preciso já não se interessar por ele; o pensamento que se deve exprimir com lucidez já tem de estar 
totalmente afastado, já não ocupar propriamente alguém. Enquanto o artista inventa e está entusiasmado, se acha, ao menos para a comunicação, num estado iliberal. Pretenderá dizer tudo, o que é uma falsa tendência dos gênios jovens ou um justo preconceito de escrevinhadores velhos. (SCHLEGEL, 1991, p. 25).

O estado denominado por Schlegel de iliberal denota a necessidade da autolimitação, isto é, do distanciamento que o artista deve buscar para ser capaz de observar sua obra, a partir de uma posição onde não se encontre tão próximo que não seja capaz de criticar a si mesmo, e táo entusiasmado que se torne cego às próprias limitaçóes. Significa, em acréscimo, que é necessário ao artista não estar ainda imbuído pelo entusiasmo, a ponto de não ter a capacidade de observar com clareza a obra de arte, o processo de criação, e o resultado obtido. Enquanto um dos modos de atuação da ironia romântica, a autolimitação é fundamental para a necessária exteriorização artística. Como foi destacado, ela é o resultado do movimento realizado pelo artista, em um ato de liberdade, ao alçar-se por sobre sua própria obra no momento do autoaniquilamento. Ingrid Strohschneider-Kohrs (2002, p. 31) salienta a necessária atitude de autoaniquilamento como antecipaçáo à autolimitação, e que a autoelevaçáo do artista por sobre sua própria obra, por sobre seu criar, é um ato de liberdade. A autora também chama a atenção para o fato de que esses elementos ou processos devem ser compreendidos "[...] à luz da filosofia do Idealismo alemáo, para que não se corra o risco de se fazer uma leitura psicológica desses fenômenos" (STROHSCHNEIDER-KOHRS, 2002, p. 31).

\section{A questão do arbítrio na Ironia e as ConsequênCias da Crítica de Hegel}

Em suas consideraçóes sobre a liberdade e o arbítrio incondicionado na ironia romântica, Schlegel retoma a concepção, introduzida em seu StudiumAufsatz, da força artística presente no elemento interno regulador, cuja atuação, subsumida apenas à organização interior da obra, seria responsável pela objetividade observada na obra dos antigos. Ao agir de acordo com esse arbítrio incondicionado, que é uma condição fundamental para que a atitude irônica se realize, o artista náo se pauta pela mera subjetividade, mas pela liberdade e autonomia de sua escolha, ao se autolimitar, sendo capaz de agir criticamente em relação a si mesmo. Friedrich Schlegel (1991, p. 25) desenvolve o conceito de arbítrio incondicionado [unbedingter Willkür] como modo de evitar que a criação de arte adentre ou permaneça em um 
estado iliberal. Através do arbítrio incondicionado, alçando-se sobre si mesmo no momento irônico de reflexão metacrítica, o artista busca alcançar a universalidade, mesmo tratando de matéria individual. Nesse sentido, o arbítrio incondicionado tem a função de auxiliar na busca pela objetividade. A reflexão crítica do artista sobre sua obra não tem o caráter de uma subjetividade que se potencia, como afirmavam os críticos de Schlegel, porém, ao contrário, se apresenta como o signo da autolimitação e da elevação sobre si mesmo. Atuando entre a vontade e a liberdade artísticas, a ironia não permite nem a exteriorização completa do interesse subjetivo do artista, nem a completa dissoluçấo no objeto. Esse sentimento que surge da liberdade do artista "[...] é um princípio de clareza, e, ao mesmo tempo limitador, porque aponta para a consciência do que é incondicionado" (STROSCHNEIDER-KOHRS, 2002, p. 37). O movimento complexo realizado pela ironia romântica se origina não da vontade subjetiva do poeta, mas do próprio espírito da arte. Ainda que intencional, a destruição da forma não significa meramente a obediência cega ao arbítrio e à subjetividade do artista, já que sua arbitrariedade é incondicionada. Walter Benjamin (2011, p. 92) foi um dos primeiros críticos a reconhecer essa problemática, afirmando que, até a sua época, o conceito de ironia havia sido compreendido de forma unilateral, inclusive na acusaçáo de subjetivismo ilimitado. Para o crítico, a ironia não destruía a obra de arte, mas, ao contrário, contribuía para sua indestrutibilidade ao revelar, em sua exteriorizaçáo, a Ideia das formas, a forma absoluta:

A forma determinada da obra singular, que se poderia designar como a forma-de-exposição, torna-se a vítima da destruição irônica. Sobre ela, no entanto, a ironia rasga um céu da forma eterna, a Ideia das formas, a que se poderia denominar de forma absoluta, e esta atesta a sobrevida da obra que extrai desta esfera sua existência indestrutível, depois que a forma empírica, a expressão de sua reflexão isolada, tenha sido consumida por ela [...] A obra é um mistério da ordem, revelação de sua absoluta dependência com relação à Ideia da arte, de seu eterno e indestrutível sersuperado na mesma. Neste sentido, Schlegel conhece os limites da obra visível, além dos quais se abre o âmbito da obra invisível, da Ideia da arte. (BENJAMIN, 2011, p. 93).

Grande parte da confusão na recepção da ironia romântica tem relação com a conclusão equivocada de que o artista age apenas conforme seu arbítrio, com a única intenção de expor sua subjetividade, aniquilando e subordinando tudo o mais à sua vontade. Essa leitura se origina na crítica severa de Hegel 
ao conceito de ironia em Schlegel. Conforme o filósofo (1973, p. 347), a ironia romântica seria uma subjetividade sem substância, ou seja, a mera expressão do subjetivismo vazio e do aniquilamento de qualquer possibilidade de conhecimento do mundo. Para Hegel, (1973, p. 348), do alto da retórica mística de suas pequenas certezas, o irônico romântico contemplaria o mundo ao redor como quem despreza qualquer conhecimento. Dessa maneira, quem defendesse o ponto de vista dessa ironia romântica schlegeliana, segundo a qual tudo o mais náo passa de uma substância vazia, observaria os outros de uma forma superior, como se sua verdade mística fosse inalcançável.

De acordo com Oskar Walzel (1985, p. 91), a leitura que Hegel fez da ironia romântica de Schlegel foi intermediada por sua compreensão do fenômeno na obra de outro filósofo, Karl Wilhelm Ferdinand Solger (17801819), cuja teoria sobre a ironia serviria de base não apenas para as consideraçóes hegelianas, mas influenciaria também grande parte da recepção posterior do conceito. Solger teria se apoderado do conceito de ironia romântica de Schlegel e o "aperfeiçoado", levando-o até onde ele não conseguira alcançar, pois "[...] se paralisara no mais extremo âmbito da subjetividade" (WALZEL, 1985, p. 91). Nesse sentido, Hegel afirma que a ironia romântica é uma "[...] figura que não apenas torna fútil todo conteúdo ético dos direitos e deveres, das leis, não é apenas o mal, o mal em si mesmo totalmente universal, mas também o saber desse mal" (SUZUKI, 1998, p. 152). O filósofo atacaria igualmente o que considerava ser a incorporação errônea da negatividade da filosofia de Fichte, acusando Schlegel de superficialidade, ausência de reflexão filosófica, e de não haver compreendido os conceitos fichteanos em sua teoria da ironia. Soma-se a esse quadro negativo o fato de que Hegel possuía uma visão completamente crítica sobre a assimilação da ironia socrática à ironia romântica, imputando a Schlegel a acusação de haver pervertido a ironia socrática. O resultado disso é que, “[...] a despeito de todo o esforço de Schlegel em aproximar uma da outra, a distinção hegeliana entre ironia socrática e ironia romântica fez escola" (SUZUKI, 1998, p. 164), determinando também como grande parte da crítica posterior, inclusive Søren Kierkegaard (18131855), compreenderia a ironia romântica de Schlegel. Essa crítica talvez não leve em consideração a amplitude do conceito de ironia romântica advinda de Schlegel por desconhecimento de seus escritos, ou até mesmo em face de sua terminologia muitas vezes hermética. É mesmo possível imaginar que termos como "autocriação", "autoaniquilamento", "autolimitação", "bufonaria transcendental", entre outros, possam se tornar uma verdadeira dificuldade para a compreensão da dinâmica do processo de ironia schlegeliana. Contudo, 
essa complexidade terminológica não seria suficiente para justificar as diversas acusaçóes imputadas à ironia schlegeliana. De qualquer modo, a partir de Hegel, a ironia seria identificada ao excesso de subjetividade, como uma "[...] versão exacerbada do sujeito fichteano, a qual aniquila e futiliza tudo o que este ainda conservava de moralmente relevante" (SUZUKI, 1998, p. 164).

\section{IRONIA ROMÂNTICA: OBJETIVIDADE OU SUBJETIVIDADE?}

A crítica de Hegel também contribuiu para a compreensão equivocada sobre o âmbito da subjetividade e da objetividade na ironia romântica de Schlegel. Ao atribuir ao fenômeno o caráter de uma simples imersão subjetiva, diversos críticos desconsiderariam o fato de que a ironia romântica não é uma forma de arrogância perante o mundo, um desencontro do sujeito ensimesmado, pois ignoraram o duplo movimento de entrada e saída de si do sujeito irônico (SUZUKI, 1998, p. 181). Ao alçar-se por sobre si mesmo e sobre sua obra, o artista é capaz de observar e refletir sobre o processo de criação artística, autoaniquilando e autolimitando a arte literária. Esse procedimento complexo, que exige do autor a sinceridade e a capacidade de se distanciar de sua obra, se complementa no ato de autolimitação, no distanciamento reflexivo necessário à autocrítica:

A leitura hegeliana náo leva em conta, talvez por desconhecimento dos textos, que a tendência à interiorizaçáo contida na ironia representa apenas uma de suas faces, que nada é sem o seu reverso [...] Como falar de aniquilamento de todo objetivo e de exacerbação do eu individual, se este não se reconhece senão através de seus mediadores? $\mathrm{O}$ indivíduo se autolimita, abre mão do todo, para assim poder se abrir ao todo. (SUZUKI, 1998, p. 164).

A questão de saber se a ironia romântica conduziria ao âmbito da subjetividade ou da objetividade divide a recepção crítica de Schlegel. Estabelecendo uma classificação detalhada de críticos da ironia schlegeliana, Raymond Immerwahr (1985, p. 113) assevera que, enquanto alguns autores afirmam ser a ironia de Schlegel a afirmação da subjetividade, há os estudiosos que compreenderiam a ironia como o caminho para exteriorizar o objetivo. Curiosamente, Schlegel considerava até mesmo a épica de Homero como uma obra onde residiria a ironia, mesmo que nela, como se sabe, não haja reflexão filosófica. Como analisa Oskar Walzel (1985, p. 85), a construção da aparência de desaparecimento do autor na obra de Homero é também o resultado da 
ironia. Enquanto distanciamento crítico do artista em relação à sua própria obra, a indiferença do autor contribui para a valoração objetiva da obra, de modo que o que prevalece não é a vontade do sujeito, mas a necessidade interna da obra. Nesse ponto, a ironia equivale ao referido elemento interno regulador, contemplado por Schlegel no Studium-Aufsatz, pois sua presença indica uma autoelevação consciente do autor por sobre a obra de arte literária.

A objetividade épica e sua relação com a ironia romântica foi ainda apontada por F. W. J. Schelling (1775-1854). O distanciamento irônico, obtido esteticamente através da indiferença do autor em relação ao herói, pode tanto encontrar-se na épica homérica quanto no protótipo de romance objetivo para Schlegel, a obra Wilhelm Meister, de Johann Wolfgang Goethe (1749-1832), como percebeu Schelling:

Uma vez que o romance deve ser, tanto quanto possível, igual à epopeia na forma da expressáo, mas uma vez que é propriamente um objeto limitado que constitui a matéria, o poeta tem de substituir a validez universal épica por uma indiferença para com o objeto principal ou para com o herói, relativamente ainda maior do que aquela que é praticada pelo poeta épico [...] Essa indiferença pode ser levada a tal ponto, que pode se converter, inclusive, em ironia com o herói, pois a ironia é a única forma em que aquilo que provém, ou tem de provir, do sujeito é o que dele mais determinadamente de novo se desprende e se torna objetivo. Nesse aspecto, portanto, a imperfeição em nada pode prejudicar o herói; a pretensa perfeiçáo, ao contrário, aniquilará o romance. Disso também faz parte o que, com particular ironia, Goethe póe na boca do próprio protagonista do Wilhelm Meister, quando o faz falar sobre a força retardante do herói. (SCHELLING, 2001, p. 301).

Entretanto, nem todos os críticos foram unânimes na compreensão do lugar da objetividade na ironia romântica de Schlegel. Rudolf Haym, em sua obra clássica $A$ escola romântica, (1870, p. 261), postula que a objetividade teria sido central no Studium-Aufsatz, mas, de forma equivocada, compreende que a ironia romântica seria uma ruptura com a necessidade de objetividade. Para Haym, ao se alçar sobre si mesmo, o poeta exteriorizaria o mais elevado subjetivismo, concretizando o oposto da preocupação predominante no Studium-Aufsatz. O crítico chega mesmo a afirmar que "[...] agora a lei da ironia substituiu a lei da objetividade" (HAYM, 1870, p. 261). Por outro lado, alguns estudiosos interpretariam a individualidade do sujeito irônico como uma saída para a objetividade. Essa oscilação da crítica na recepção da ironia romântica talvez seja o resultado da incompreensão sobre a aplicação prática 
do conceito. Aqueles que defendem a ironia enquanto um fenômeno que induz à subjetividade partem da dedução de que a ironia seria a aniquiladora da ilusão ficcional, enquanto os defensores da objetividade afirmam que Schlegel não se referia à ilusão ficcional, e muito menos ao Gato de botas, peça publicada em 1793 por Ludwig Tieck (1773-1853), exemplo clássico de quebra da ilusão ficcional (IMMERWAHR, 1985, p. 113). Esses críticos acreditavam que a ironia não significaria a destruição intencional da ficção por parte do autor, mas, ao contrário, sua legitimação através da atitude irônica que pairava sobre a obra. A característica fluida e muitas vezes indeterminável da ironia romântica, que se baseia na referida atopía socrática, determina sua aparição até mesmo em um gênero eminentemente objetivo, como é o caso da epopeia. Quando surge como o distanciamento crítico do artista em relaçáo à sua própria obra, a ironia romântica contribui para a valoração objetiva da obra, fazendo prevalecer não a vontade do sujeito, porém, a necessidade interna da obra. A ironia é uma importante ferramenta de problematizaçáo do ato criador em toda a sua plenitude e, enquanto meio de autorrepresentação da obra, ela é "[...] uma faculdade que permite o jogo lúdico e dialético da arte em sua realidade estética” (STROHSCHNEIDER-KOHRS, 2002, p. 70). Relacionada ao processo de criação artística e instrumento essencial para a problematização que o artista estabelece em relação à sua arte, ela também representa sua crítica e autocrítica, assim como a reflexão e a saída de si mesmo. Além disso, enquanto dialética que se revela no modo de exposiçáo, a ironia romântica torna-se "[...] um instrumento artístico que provoca a ruptura de formas estabelecidas na arte” (YOON, 1996, p. 90).

\section{IRONIA ROMÂNTICA E ININTELIGIBILIDADE}

Outro aspecto muito importante da ironia romântica de Friedrich Schlegel está relacionado à compreensão da arte literária, ou melhor, às condiçóes de sua inteligibilidade. No ano de 1800, com o intuito irônico de auxiliar aqueles que tinham certa dificuldade em compreender seus fragmentos, por considerarem seu estilo hermético e enigmático, Schlegel publica Sobre a Ininteligibilidade, [Über die Unverständlichkeit], onde realiza uma classificação sistemática da ironia (SCHLEGEL, 1967, p. 369). De acordo com essa taxonomia schlegeliana da ironia, o fenômeno compreenderia desde a ironia grosseira ou rude [Grobe Ironie], a ironia fina ou delicada [die feine oder die delikate Ironie], a ironia extrafina [die extrafeine], a ironia séria [redliche Ironie], a ironia dramática [die dramatische Ironie], a ironia dupla [die doppelte Ironie], 
até chegar à ironia da ironia [die Ironie der Ironie] (SCHLEGEL, 1967, p. 369). Apontando para o fato de que certa dose de incompreensão é muitas vezes parte integrante de qualquer texto literário, e mesmo de toda comunicaçáo humana, o crítico também questionaria "[...] se a ininteligibilidade seria mesmo tão reprovável e ruim" (SCHLEGEL, 1967, p. 370). O escrito Sobre a Ininteligibilidade ainda tem relação com outro elemento muito importante para o âmbito da crítica literária: a hermenêutica. Para ser capaz de compreender o que se situaria entre a letra e o espírito de um texto, enquanto instrumento da exegese crítico-literária, a hermenêutica deveria considerar o fato de que toda comunicação humana é também signo de uma limitação. Além da consciência desse limite, oculto nas arestas e partes ininteligíveis de um texto, a hermenêutica schlegeliana pressupóe a compreensáo simultânea das partes e do todo, na obra de arte literária. É por essa razão que Schlegel afirma "[...] que não se deveria procurar entender apenas os belos trechos da obra, mas sua relação com o todo" (SCHLEGEL, 1967, p. 410). Na concepção de hermenêutica desenvolvida por Schlegel e F. D. E. Schleirmacher (1768-1834), levar em conta esse âmbito do indizível, do inexplicável, do inenarrável, significaria compreender um autor muitas vezes melhor do que ele mesmo se compreendera (SCHLEGEL, 1991, p. 128). Como instrumento desse movimento contínuo de análise crítico-literária, a ironia romântica possibilitaria a rapidez de espírito e a clareza de consciência, tanto para o detalhe filológico e a visão do todo quanto para a observaçấo do que se encontra entre o espírito e a letra. No primeiro romantismo alemáo, a crítica se torna a "[...] comparação entre o espírito e a letra de uma obra, que é tratada como infinito, como absoluto e como indivíduo" (SCHLEGEL, 1981, p. 168). Através do processo de autoaniquilamento e autolimitação, a ironia transforma a obra no locus da problematização metacrítica e filosófica, que, como o mediumde-reflexão a que se referia Walter Benjamin (2011, p. 93), unifica os âmbitos da poesia, da filosofia e da crítica literária. O bufẫo transcendental e o bufẫo italiano comum representam, de certo modo, os dois âmbitos de atuação da ironia, ou seja, no conteúdo e na forma da arte, refletindo de modo sério sobre a matéria $\mathrm{da}$ arte, e brincando ironicamente sobre essa mesma reflexão. $\mathrm{O}$ movimento duplo realizado pela ironia problematiza intencionalmente o conteúdo e a forma da expressão literária. Como aponta Márcio Suzuki (1998, p. 180), ao unificar os pontos de vista transcendental e comum, entrecruzando poesia e filosofia, o sábio do romantismo eleva a arte ao transcendental, mas, ao mesmo tempo, não permite o distanciamento do filósofo da vida real. 


\section{IRONIA É ÂNSIA DE INFINITO E MISTÉRIO DA ORDEM}

Inserida por Friedrich Schlegel no centro de sua teorização críticoliterária, a ironia romântica apresenta-se como atitude espiritual e forma de exposição da arte, elevando-a acima de todo condicionado como verdadeira "[...] échappé de vue para o infinito" (SCHLEGEL, 1991, p. 85). Significativa para o processo de criação, enquanto elevação consciente e livre do artista acima de sua própria criação, ela também é medium e agente de rupturas, seja por sua atuação no conteúdo, seja como forma de expressão irônica. No cerne dessa literatura que toma a si mesma como objeto de reflexão críticoliterária, a ironia unifica a poesia e a filosofia. Em seu caráter progressivo e no movimento centrífugo e centrípeto de sua manifestação, expõe a obra, o momento de reflexão criadora e até mesmo a singularidade do autor. Forma do paradoxo e beleza lógica, conforme afirmou Friedrich Schlegel (1991, p. 28), ela reside até mesmo na atitude de generosidade e sinceridade do artista perante sua criação artística. $\mathrm{Na}$ indiferença e no desaparecimento do autor em face do sofrimento e desespero do herói épico, e na consciência do abismo que separa os homens no romance, o conceito de ironia representa a seriedade reflexiva desse poeta filósofo, que contempla o incondicionado a partir da limitação de seu ser. Todavia, ela reside ainda no riso irônico do bufẫo italiano que reconhece a condição frágil e inconstante da existência do homem. Atitude séria e reflexiva do bufăo transcendental, mas também brincadeira capaz de transformar o filósofo em homem comum e fazê-lo rir de si mesmo, a ironia atenua o sentimento de fragilidade em face do infinito. Emprestando dignidade e leveza à alma humana, ela é a clareza de consciência e a agilidade da mente, assim como o instrumento alado desse espírito romântico que "[...] parece fantasiar agradavelmente sobre si mesmo” (SCHLEGEL, 1991, p. 131). 
MEDEIROS, Constantino Luz de. The Form of Paradox: Friedrich Schlegel and the Romantic Irony. Trans/Form/Ação, Marília, v. 37, n. 1, p. 51-70, Jan./Abril, 2014.

\begin{abstract}
Defined as logical beauty and form of paradox, Friedrich Schlegel's (1772-1829) romantic irony incorporates ancient Socratic irony and reinterprets it, inserting it as a nuclear element of his theorization on literary criticism. The current paper analyses the concept of romantic irony seeking to situate its alterations at the end of 18 th century, when it changed its meaning for metacritics, philosophical reflexion, fictional rupture, aesthetical distance and form of art exposition.
\end{abstract}

KEY-WORDS: Friedrich Schlegel. Romantic irony. Socratic irony. History of Literary Criticism. Early German Romanticism.

\title{
REFERÊNCIAS
}

BEEKS, Robert. Etymological Dictionary of Greek. Vol. I. Boston: Brill, 2010.

BEHLER, Ernst. Ironie und literarische Moderne. Paderborn: Ferdinand Schöningh, 1997. Klassische Ironie. Romantische Ironie. Tragische Ironie. Zum Ursprung dieser Begriffe. Darmstadt: Wissenschaftliche Buchgesellschaft, 1972.

BENJAMIN, Walter. O conceito de critica de arte no Romantismo alemão. Tradução de Márcio Seligmann-Silva. São Paulo: Iluminuras, 2011.

CUDDON, J. A. Dictionary of Literary Terms and Literary Theory. London: Penguin Reference Books, 1999.

FICHTE, Johann Gottlieb. Fichtes Werke. Bd. I. Berlin: Walter de Gruyter, 1971.

HAYM, Rudolf. Die Romantische Schule. Hildesheim - New York: Georg Olms, 1977. [Reprodução fotomecânica da obra original de 1870].

HEGEL, Georg Wilhelm Friedrich. Die Ironie. In: HASS, Hans-Egon; MOHRLÜDER, Gustav-Adolf. Ironie als literarisches Phänomenon. Köln: Kiepenheuer \& Witsch, 1973, p. 340-349.

IMMERWAHR, Raymond. The subjectivity or objectivity of Friedrich Schlegel's poetic irony. In: SCHANZE, Helmut. (Hrsg.) Friedrich Schlegel und die Kunsttheorie seiner Zeit. Darmstadt: Wissenschaftliche Buchgesellschaft, 1985, p. 112-142.

KNOX, Norman. Die Bedeutung von Ironie. Einführung und Zusammenfassung. In: HASS, Hans-Egon; MOHRLÜDER, Gustav-Adolf. Ironie als literarisches Phänomenon. Köln: Kiepenheuer \& Witsch, 1973, p. 21-30.

SCHELlinG, F. W. J. Filosofia da Arte. São Paulo: Edusp, 2001. Tradução de Márcio Suzuki. 
SCHLEGEL, Friedrich. O dialeto dos fragmentos. Tradução de Márcio Suzuki. São Paulo: Iluminuras, 1991. STROHSCHNEIDER-KOHRS, Ingrid. Die romantische Ironie in Theorie und Gestaltung. Tübingen: Max Niemeyer, 2002.

. Fragmente zur Poesie und Literatur. In: Kritische Friedrich-Schlegel-Ausgabe. Bd. XVI. Paderborn: Ferdinand Schöningh, 1981.

. Studien des Klassischen Altertums. In: Kritische Friedrich-Schlegel-Ausgabe. Bd. I. Paderborn: Ferdinand Schöningh, 1979.

Kritische Fragmente. In: Kritische Friedrich-Schlegel-Ausgabe. Bd. II. Paderborn: Ferdinand Schöningh, 1967.

. Philosophische Lehrjahre. In: Kritische Friedrich-Schlegel-Ausgabe. Bd. XVIII. Paderborn: Ferdinand Schöningh, 1963.

SUZUKI, Márcio. Sobre Música e Ironia. Idealismo Alemão. Revista Dois Pontos. Curitiba - São Carlos, v. 4, n. 1, p. 175-200, 2007.

. O gênio romântico. Crítica e História da Filosofia em Friedrich Schlegel. São Paulo: Iluminuras, 1998.

VENDRAMINI, José Eduardo. A commedia dell'arte e sua reoperacionalização. Trans/ Form/Ação. Marília, v. 24, n. 1, p. 57-83, 2001.

WALZEL, Oskar. Methode? Ironie bei Friedrich Schlegel und bei Solger. In: SCHANZE, Helmut. (Hrsg.) Friedrich Schlegel und die Kunsttheorie seiner Zeit. Darmstadt: Wissenschaftliche Buchgesellschaft, 1985, p. 71-94.

YOON, Tae Won. Der Symbolcharakter der neuen Mythologie im Zusammenhang mit der kritischen Funktion der romantischen Ironie bei Friedrich Schlegel. Frankfurt am Main: Peter Lang, 1996.

Submissão: 30/09/2013

Aceito em: 22/11/2013 